\title{
Serum Transferrin Receptor for Assessment of Iron Status in Healthy Prepubertal and Early Pubertal Boys
}

\author{
SANNA M. KIVIVUORI, RAIJA ANTTILA, LASSE VIINIKKA, KRISTINA PESONEN, AND \\ MARTTI A. SIIMES
}

Children's Hospital, University' of Helsinki, Helsinki, Finland

\begin{abstract}
A recently introduced test measures the concentration of transferrin receptor (TfR) in serum, which increases shortly after the onset of iron deficiency. In adults this increase reflects the degree to which tissue iron availability is impaired. We developed a fluoroimmunoassay to quantify TfR. The purpose of this study was to evaluate the role of TfR as an index of iron sufficiency in 62 healthy prepubertal or early pubertal boys. The mean concentration of serum TfR was $3.8(-1 \mathrm{SEM}=3.6,+1 \mathrm{SEM}=3.9)$ $\mathrm{mg} / \mathrm{L}$. No associations were observed between the serum TfR and the concentration of $\mathrm{Hb}$, the values of packed cell volume, reticulocyte production index, mean corpuscular $\mathrm{Hb}$, mean corpuscular volume, or the concentrations of serum iron, transferrin, or ferritin. Because none of the subjects had signs of iron deficiency, we determined the 95\% reference intervals for $\mathrm{Hb}$, red blood cell indices, and the above-mentioned serum concentrations. The reticulocyte count and reticulocyte production index were higher than expected. Our results indicated that the individual concentration of $\mathrm{TfR}$ in serum does not depend on any of the several other parameters of iron status in a group of healthy individuals. (Pediatr Res 34: 297-299, 1993)
\end{abstract}

\section{Abbreviations}

$\mathrm{MCH}$, mean corpuscular $\mathrm{Hb}$

$\mathrm{MCV}$, mean corpuscular volume

$\mathrm{PCV}$, packed cell volume, hematocrit

RPI, reticulocyte production index

$T f R$, transferrin receptor

Evaluation of iron stores would be of great clinical use, but reliable values can be obtained only with invasive methods, which include repeated venesection (1). The concentration of $\mathrm{TfR}$ in serum is a new measure that reflects iron status (2-4). It seems to have several advantages over other tests. Although individuals with low serum ferritin concentrations, below $20 \mu \mathrm{g} /$ $\mathrm{L}$, probably have iron deficiency and those with high serum ferritin concentrations, above $100 \mu \mathrm{g} / \mathrm{L}$, probably have sufficient iron nutrition, most healthy subjects have intermediate values (5). Serum TfR may prove to be a more sensitive indicator of iron deficiency in this group. On the other hand, serum ferritin may be the most sensitive index of iron status when there are residual iron stores, whereas the serum receptor may be more sensitive when there is functional iron deficiency (1). Unlike

Received October 15, 1992; accepted March 30, 1993.

Correspondence and reprint requests: Sanna-Maria Kivivuori, M.D., Fellow in Pediatric Hematology, Research Laboratory, Children's Hospital, University of Helsinki, Stenbäckinkatu 11, SF-00290 Helsinki, Finland. serum ferritin concentration, serum TfR can not be influenced by infections or chronic inflammation (5). It becomes elevated soon after iron deficiency appears, and the increase reflects the magnitude in the impairment of tissue iron availability better than other tests (1). The value of serum TfR measurement has been established in adult populations, but no studies on the role of serum TfR in children are available $(1,4)$. We have developed a new method for measuring serum TfR and evaluated its value as an index of iron sufficiency in a group of healthy prepubertal or early pubertal boys who do not have iron deficiency.

\section{MATERIALS AND METHODS}

Subjects. We offered this clinical and laboratory evaluation to the sons of 84 families in the three classes in the three schools closest to Helsinki Children's Hospital. Most families in the area represent the middle or upper middle class. Of these 84 boys, 62 visited the clinic after informed consent had been obtained from the parents. This study was approved by the hospital's Committee of Ethics. According to medical histories and physical examinations, all boys were healthy except two, who occasionally used budesonide for asthma. They were included in the study. The mean age of the boys was $11.7 \pm 0.04 \mathrm{y}$. The mean body weight was $40.1 \pm 1.0 \mathrm{~kg}$, and the mean height was $149 \pm 0.9 \mathrm{~cm}$. The pubertal stage according to Tanner was Pl Gl in 34 boys and more advanced in different combinations in 28 boys. However. none had reached the stage P3 G3.

Methods. Venous blood samples for measurement of $\mathrm{Hb}$ concentration, PCV, reticulocyte count, red cell indices, concentrations of serum iron, transferrin, ferritin, and TfR were drawn between 0900 and $1400 \mathrm{~h}$. For all measurements, results were obtained from the 62 boys, except in one boy in which the reticulocyte count was lacking.

$\mathrm{Hb}$ concentration, $\mathrm{PCV}, \mathrm{MCH}$, and $\mathrm{MCV}$ were measured with an automatic counter. The reticulocyte count was determined microscopically, using brilliant cresyl blue staining. RPI was estimated (6):

$$
\begin{aligned}
& \text { [reticulocyte count }(\%) / \text { reticulocyte maturation time }(\mathrm{d})] \\
& \times[\operatorname{PCV}(\%) / 45]
\end{aligned}
$$

The serum iron concentration was measured colorimetrically. The transferrin concentration was measured with a turbidimetric method and the concentration of serum ferritin with an RIA using commercial reagents (Ferritin RIA Kit, Amerlex Product, Kodak Clinical Diagnostics, Amersham, UK).

For measuring the concentration of TfR in serum, we developed a two-step sandwich-type time-resolved immunofluorometric assay. Two mouse MAb (E2H10 and A4A6) against serum TfR were kindly supplied by Dr. James D. Cook, Kansas University Medical Center, Kansas City, KS. The antibodies have been used earlier for an ELISA of TfR (4). The IgG fractions 
from ascites fluid were purified by affinity chromatography using a HiTrap Protein G Sepharose column (Pharmacia LKB, Uppsala, Sweden) according to the manufacturer's instructions, except

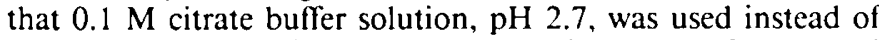
glycine, and $1 \mathrm{M}$ sodium carbonate solution, $\mathrm{pH} 11.9$, was used instead of Tris buffer.

For the solid phase we used polystyrene microtiter strips, each consisting of 12 wells (Labsystems, Helsinki, Finland). The wells were coated with $200 \mu \mathrm{L}$ of a solution containing $5 \mu \mathrm{g} / \mathrm{mL}$ of the IgG fraction from E2H10 in $50 \mathrm{mM}$ sodium bicarbonate buffer, $\mathrm{pH} 9.25$, for about $24 \mathrm{~h}$ at room temperature. Then the wells were washed with a washing solution containing $0.9 \%$ $\mathrm{NaCl}, 0.05 \%$ Tween 20 , and $0.05 \% \mathrm{NaN}_{3}$. The strips were stored at $+4^{\circ} \mathrm{C}$ in a moist atmosphere.

The IgG fraction purified from A4A6 was labeled with europium (Eu3+) using Europium-Labelling Reagent according to the instructions of the manufacturer (LKB Wallac, Turku, Finland) (7).

For the time-resolved immunofluorometric assay, we transferred into coated microtiter wells $100 \mu \mathrm{L}$ of sample or standard in duplicate measurements diluted in Delfia assay buffer solution $\left(0.15 \mathrm{M} \mathrm{NaCl}, 0.05 \% \mathrm{NaN}_{3}, 20 \mu \mathrm{M}\right.$ diethylenetriaminepentaacetic acid, $0.5 \%$ BSA, $0.05 \%$ bovine $\gamma$-globulin, and $0.01 \%$ Tween 40 in $0.1 \mathrm{M}$ Tris- $\mathrm{HCl}$ buffer, pH 7.75, LKB Wallac) containing $6.5 \%$ BSA (Wilfrid Smith, Middlesex, England) to mimic serum. We added $100 \mu \mathrm{L}$ of assay buffer solution and incubated the wells for $3 \mathrm{~h}$ at room temperature with continuous gentle shaking (Wallac Plate Shake 1296-001, LKB Wallac). The wells then were washed three times with the washing solution, and $100 \mathrm{ng}$ of Eu-labeled IgG in $200 \mu \mathrm{L}$ of the assay buffer were added. After a further incubation for $2.5 \mathrm{~h}$ at room temperature with continuous gentle shaking, we washed the wells six times and added $200 \mu \mathrm{L}$ of Delfia enhancement solution $(0.01 \%$ Triton $\mathrm{X}-100,15 \mu \mathrm{M}$ 2-naphthoyltrifluoroacetone, and $50 \mu \mathrm{M}$ tri-noctylphosphine oxide in $0.1 \mathrm{M}$ acetate-phthalate buffer, $\mathrm{pH} 3.2$. LKB Wallac). We shook the wells gently and after $60 \mathrm{~min}$ measured the fluorescence with a 1230 Arcus Fluorometer (LKB Wallac) using counting time of $1 \mathrm{~s}$ and time delay of $400 \mu \mathrm{s}(8)$.

A standard curve was produced by diluting a serum pool with assay buffer containing $6.5 \%$ BSA. The TfR concentration of this pool was measured against the TfR purified from human placenta, also donated by Dr. James Cook. The linear part of the standard curve covered the concentration range $0.0052-$ $0.261 \mathrm{mg} / \mathrm{L}$. The unknown samples were assayed at two different dilutions (1:51 and 1:102), both in duplicate. Thus, our assay covered the final serum concentration of 0.27 to $26.6 \mathrm{mg} / \mathrm{L} \mathrm{TfR}$. The parallelism between the two serum dilutions and the standard curve was a prerequisite for acceptance of the assay. As controls we used two dilutions (1:50 and 1:100) of a different serum pool containing $6.4 \mathrm{mg} / \mathrm{L} \mathrm{TfR}$.

The interassay coefficients of variation were 12.8 and $16.9 \%$ $(n=6)$ and the intraassay coefficients of variation were $11.4 \%$ and $8.2 \%(n=20)$ with $1: 100$ and 1:50 dilutions of the control pool, respectively. When known amounts of TfR were added to the serum samples, a mean of $96.8 \%$ of the calculated value was recovered (coefficient of variation $15.5 \%, n=33$ ).

Statistical analysis. For statistical analysis unpaired two-tailed $t$ test and simple regression analysis were used. When the $t$ test was not applicable, we used the Mann-Whitney $U$ test. A value of $p<0.05$ was considered significant. Means \pm SEM are used unless otherwise mentioned. Because the distributions of serum TIR and ferritin values were skewed, the data were transformed into logs. For these measures, geometric means were calculated. Because the distribution of RPI was skewed even after log transformation, a nonparametric procedure was used for the determination of reference values.

\section{RESULTS}

None of the subjects had any evidence of iron deficiency anemia. Even those with the lowest $\mathrm{Hb}$ concentrations did not have any other signs of iron deficiency (such as low MCH, MCV, or serum ferritin concentration, or high transferrin concentration). Of the 62 boys, one had serum ferritin concentration below $10 \mu \mathrm{g} / \mathrm{L}$. In this case all other laboratory results were within normal range.

The geometric mean concentration of serum TfR was $3.8(-1$ $\mathrm{SEM}=3.6,+1 \mathrm{SEM}=3.9) \mathrm{mg} / \mathrm{L}$. The values ranged from 2.3 to $7.3 \mathrm{mg} / \mathrm{L}$. The mean concentration of TfR was $3.8(-1 \mathrm{SEM}$ $=3.6,+1 \mathrm{SEM}=4.0) \mathrm{mg} / \mathrm{L}$ in the boys whose puberty was $\mathrm{Pl}$ G1 and $3.6(-1$ SEM $=3.4,+1$ SEM $=3.8) \mathrm{mg} / \mathrm{L}$ in the other boys. The $95 \%$ reference intervals of all the parameters measured for the prepubertal and early pubertal male population are given in Table 1.

Regression analysis showed no association between log serum $\mathrm{TfR}$ concentrations and blood $\mathrm{Hb}$ or log serum ferritin concentrations (Fig. 1). Similarly, no associations were observed between the log serum TfR concentrations and our other criteria of iron status, including the values of PCV, RPI, MCH, MCV, and the concentrations of serum iron and transferrin, and trans-

Table $1.95 \%$ reference intervals for different iron-related laboratory studies determined from results obtained from 62 healthy prepubertal or carly pubertal boys*

\begin{tabular}{lc}
\hline \multicolumn{1}{c}{ Laboratory study } & $\begin{array}{c}95 \% \text { Reference } \\
\text { intervals }\end{array}$ \\
\hline $\mathrm{Hb}(\mathrm{g} / \mathrm{L})$ & $116-144$ \\
$\mathrm{PCV}(\%)$ & $34.8-43.6$ \\
Reticulocyte count $(\%)$ & $0.70-4.00$ \\
$\mathrm{RPI}$ & $0.51-3.25$ \\
$\mathrm{MCV}(\mathrm{fl})$ & $78.8-91.4$ \\
$\mathrm{MCH}(\mathrm{pg})$ & $24.9-31.3$ \\
Serum iron $(\mu \mathrm{mol} / \mathrm{L})$ & $5.9-26.2$ \\
Serum transferrin $(\mathrm{g} / \mathrm{L})$ & $2.2-3.5$ \\
Serum transferrin saturation $(\%)$ & $7.5-35.8$ \\
Serum ferritin $(\mu \mathrm{g} / \mathrm{L})$ & $11.7-86.5$ \\
Serum TrR $(\mathrm{mg} / \mathrm{L})$ & $2.2-6.3$ \\
\hline
\end{tabular}

* Calculations of serum ferritin and TfR concentrations were performed after $\log$ transformation.
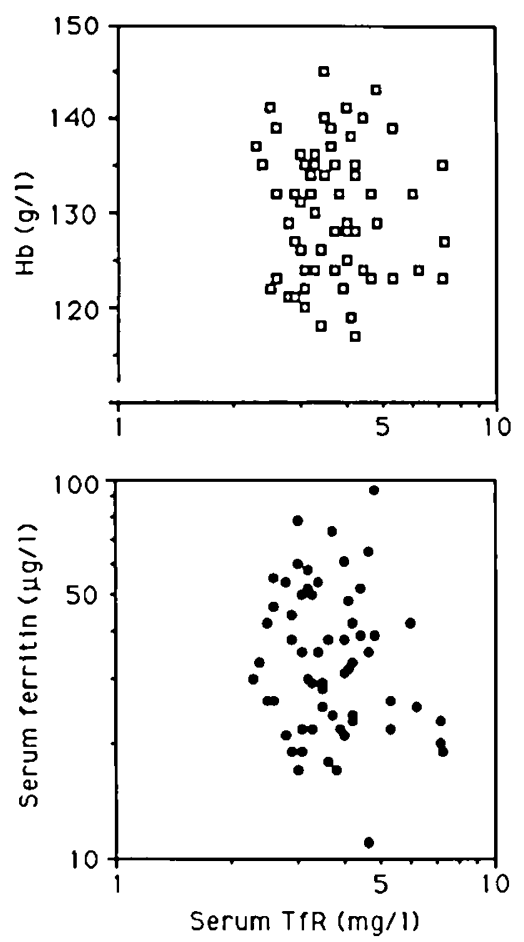

Fig. 1. Relations of the concentrations of serum TfR to blood $\mathrm{Hb}$ (upper figure) and to serum ferritin (lower figure) in 62 healthy prepubertal or early pubertal boys. 
ferrin iron saturation. When the data were divided into three categories of identical size based on TfR concentration, there were no differences among the mean values of any other iron parameters.

\section{DISCUSSION}

TfR on the cell surface controls the receptor-mediated endocytosis by which iron is delivered to the cytosol. Animal and clinical studies indicate that serum levels of TfR reflect the total mass of tissue receptor (9). Thus, the concentration of TIR in serum is the newest parameter reflecting iron status. An ELISA has been used for measurement of serum TfR (4). In 82 healthy adult volunteers, the mean concentration of serum TfR was 5.6 $\mathrm{mg} / \mathrm{L}$. No difference in serum TfR concentration was observed between men and women, which is interesting because the iron status for most iron parameters is inferior in women. Our modification of the method using a time-resolved immunofluorometric assay uses a relatively new detection principle (10). Because the method is very sensitive, it is suitable for pediatric samples; only $10 \mu \mathrm{L}$ of serum are needed for duplicate determinations.

No recent studies of the iron status in early adolescence are available from western societies. Irish adolescents from 14.5 to $18.4 \mathrm{y}$, however, were studied by Armstrong (11), who used serum ferritin concentration $<10 \mu \mathrm{g} / \mathrm{L}$ as a criterion of iron deficiency. On this basis, $40 \%$ of the adolescents were iron deficient. He concluded that the results may represent normal values for adolescents (11).

We studied a group of healthy prepubertal and early pubertal boys in whom it is assumed that iron deficiency anemia is uncommon. As expected, none of our subjects had iron deficiency anemia. However, the incidence of iron deficiency anemia depends on the cutoff point used. Our findings indicate that the point of $130 \mathrm{~g} / \mathrm{L} \mathrm{Hb}$ concentration used for adolescent males $(11,12)$ is too high at the start of puberty. Furthermore, our findings suggest that prepubertal and early pubertal boys in Finland have a high iron status.

The prepubertal and early pubertal boys had high values for the reticulocyte count and RPI. This is a new observation, which may indicate that in boys at this stage of puberty the rate of erythropoiesis is accelerated. In fact, this is expected if the background phenomena in iron metabolism are evaluated. At least four factors can result in accelerated erythropoiesis. The increase in body weight results in a respective increase in the blood volume and red blood cell volume. The $\mathrm{Hb}$ concentration in the males may start to increase at this stage of puberty. The muscle mass containing myoglobin is increasing. Consequently, this is the age period when healthy boys increase their physical activity, which can lead to a considerable increase in the proportional blood volume, which can have a marked influence on the erythropoiesis rate if the $\mathrm{Hb}$ concentration is simultaneously maintained.

It remains to be shown whether the skewed distribution of serum $\mathrm{TfR}$ concentrations is a physiologic phenomenon or whether the subjects with the highest concentrations of serum $T f R$ in our series have marginal iron deficiency. Our findings support the former possibility because the subjects with the highest values had no other indication of iron deficiency.

Interestingly, Skikne et al. (1) have observed a linear correlation between the log ratio of serum TfR concentration to serum ferritin concentration and iron stores in $\mathrm{mg} / \mathrm{kg}$ body weight during repeated phlebotomies in 14 healthy adult volunteers. In another study (13), log serum ferritin concentration showed a good correlation with estimated iron stores. In our data the interrelationship between serum ferritin and serum TfR showed that the TfR values were not any higher in individuals with relatively low serum ferritin concentrations, for instance, below $20 \mu \mathrm{g} / \mathrm{L}$. Thus, it seems that in healthy prepubertal and early pubertal boys measurement of serum TfR concentration is of little additional value for the assessment of iron status.

Acknowledgment. The authors thank Dr. James D. Cook, Kansas University Medical Center, Kansas City, KS, who kindly supplied the MAb and purified TfR.

\section{REFERENCES}

1. Skikne BS, Flowers CH, Cook JD 1990 Serum transferrin receptor: a qualitative measure of tissue iron deficiency. Blood 75:1870-1876

2. Kohgo Y, Nishisato T, Kondo H, Tsushima N, Niitsu Y, Urushizaki 11986 Circulating transferrin receptor in human serum. Br J Haematol 64:277281

3. Huebers HA, Beguin Y, Poottrakul P, Einspahr D. Finch CA 1990 Intact transferrin receptors in human plasma and their relation to erythropoiesis. Blood 75:102-107

4. Flowers CH, Skikne BS, Covell AM, Cook JD 1989 The clinical measurements of serum transferrin receptor. J Lab Clin Med 114:368-377

5. Ferguson BJ, Skikne BS, Simpson K, Baynes RD. Cook JD 1992 Serum transferrin receptor distinguishes anemia of chronic disease from iron deficiency anemia. J Lab Clin Med 119:385-390

6. Lux SE, Glader BE 1981 Disorders of the red cell membrane. In: Nathan DG Oski FA (eds) Hematology of Infancy and Childhood. WB Saunders, Philadelphia, pp 456-565

7. Hemmilä I, Dakubu S, Mukkala VM, Siitari H, Lövgren T 1984 Europium as a label in time-resolved immunofluorometric assays. Anal Biochem 137:335343

8. Soini E, Kojola H 1983 Time-resolved fluorometer for lanthanide chelates: a new generation of nonisotopic immunoassays. Clin Chem 29:65-68

9. Cook JD, Dassenko S. Skikne BS 1990 Serum transferrin receptor as an index of iron absorption. Br J Haematol 75:603-609

10. Hemmilä I 1985 Fluoroimmunoassays and immunofluorometric assays. Clin Chem 31:359-370

11. Armstrong PL 1989 Iron deficiency in adolescents. Br Med J 298:499

12. Agha F, Sadaruddin A, Khan RA, Ghafoor A 1992 Iron deficiency in adolescents. J Pak Med Assoc 42:3-5

13. Saarinen UM, Siimes MA 1979 Iron absorption from breast milk, cow's milk. and iron-supplemented formula: an opportunistic use of changes in total body iron determined by hemoglobin, ferritin and body weight in 132 infants. Pediatr Res 13:143-147 